\title{
Isolated bipallidal lesions caused by extrapontine myelinolysis
}

Figure 1 Brain MRI performed 12 days after the onset of symptoms

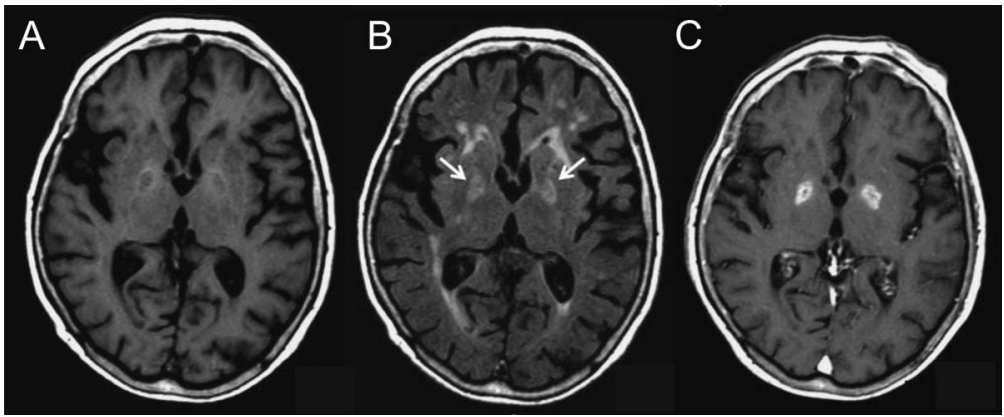

Brain MRI shows bipallidal lesions, hypointense in T1-weighted images (A), hyperintense (arrows) in T2-fluid-attenuated inversion recovery $(B)$, with contrast enhancement after gadolinium administration (C). Evidence of chronic small-vessel ischemic disease was also present (B).

Figure 2 Brain MRI after 2 months

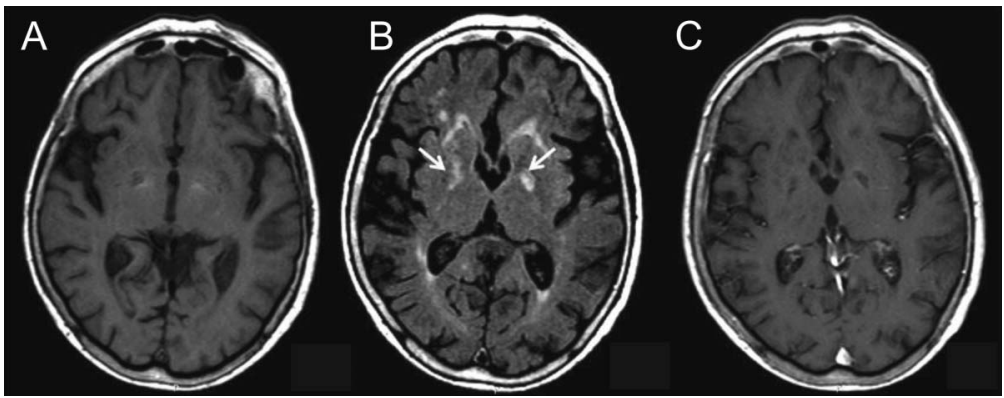

Follow-up MRI scans reveal bipallidal hypointensity on T1-weighted images (A), bipallidal hyperintensity (arrows) on fluidattenuated inversion recovery images (B), and the absence of contrast enhancement (C). A follow-up neurologic examination 2 months after the initial presentation reveals significant clinical improvement.

An 89-year-old woman developed bradykinesia, mutism, and apathy after a rapid correction of hyponatremia caused by repeated vomiting. Brain MRI showed bipallidal involvement that improved at follow-up (figure 1, figure 2). The patient's clinical history and neuroimaging are suggestive of extrapontine myelinolysis. This disease involves basal ganglia but the globus pallidus is usually spared or not singly involved. ${ }^{1}$ A patient with bipallidal extrapontine myelinolysis has been previously described. ${ }^{2}$ Toxic, hypoxic, and metabolic causes of bipallidal involvement were excluded in our patient. Extrapontine myelinolysis should be included in the differential diagnosis of patients with a history of hyponatremia, subacute parkinsonism, and bipallidal lesions on MRI.

Gianluca Floris, MD, Francesca Di Stefano, MD, Rosanna Melis, MD, Maria Valeria Cherchi, MD, Francesco Marrosu, MD

From the Departments of Neurology (G.F., F.D.S., R.M., F.M.) and Radiology (M.V.C.), Azienda Universitaria-Ospedaliera of Cagliari and University of Cagliari, Italy.

Author contributions: Gianluca Floris: drafting/revising the manuscript, study concept, analysis of data. Francesca Di Stefano: drafting/ revising the manuscript, study design, analysis and acquisition of data. Rosanna Melis: drafting/revising the manuscript, acquisition of data. Maria Valeria Cherchi: drafting/revising the manuscript, acquisition of radiologic data. Francesco Marrosu: drafting/revising the manuscript, study supervision. 
Study funding. No targeted funding reported.

Disclosures: The authors report no disclosures relevant to the manuscript. Go to Neurology.org for full disclosures.

Correspondence to Dr. Floris: lgr.floris@tiscali.it

1. Gocht A, Calmant HJ. Central pontine and extrapontine myelinolysis: a report of 58 cases. Clin Neuropathol 1987;6:262-270.

2. Hsieh CY, Huang CW. Extrapontine myelinolysis in a patient following correction of hyponatremia. Acta Neurol Taiwan 2007; 16:188-189.

\section{NeuroImages Are Free at www.neurology.org!}

All Neurology ${ }^{\circledR}$ NeuroImages can now be freely accessed on the Neurology Web site. See them at www.neurology.org, where you can also sign up for journal email alerts and check out other online features, including the Resident \& Fellow section, Neurology: Clinical Practice, and the weekly Neurology Podcasts. 


\section{Neurology}

\section{Isolated bipallidal lesions caused by extrapontine myelinolysis \\ Gianluca Floris, Francesca Di Stefano, Rosanna Melis, et al. Neurology 2013;81;1722-1723 \\ DOI 10.1212/01.wnl.0000435297.80023.9e}

\section{This information is current as of November 4, 2013}

\section{Updated Information \&} Services

References

Subspecialty Collections

Permissions \& Licensing

Reprints including high resolution figures, can be found at: http://n.neurology.org/content/81/19/1722.full

This article cites 2 articles, 0 of which you can access for free at: http://n.neurology.org/content/81/19/1722.full\#ref-list-1

This article, along with others on similar topics, appears in the following collection(s):

All Movement Disorders

http://n.neurology.org/cgi/collection/all_movement_disorders

Basal ganglia

http://n.neurology.org/cgi/collection/basal_ganglia

MRI

http://n.neurology.org/cgi/collection/mri

Parkinson's disease/Parkinsonism

http://n.neurology.org/cgi/collection/parkinsons_disease_parkinsonism

Information about reproducing this article in parts (figures,tables) or in its entirety can be found online at:

http://www.neurology.org/about/about_the_journal\#permissions

Information about ordering reprints can be found online:

http://n.neurology.org/subscribers/advertise

Neurology ${ }^{\circledR}$ is the official journal of the American Academy of Neurology. Published continuously since 1951, it is now a weekly with 48 issues per year. Copyright @ 2013 American Academy of Neurology. All rights reserved. Print ISSN: 0028-3878. Online ISSN: 1526-632X.

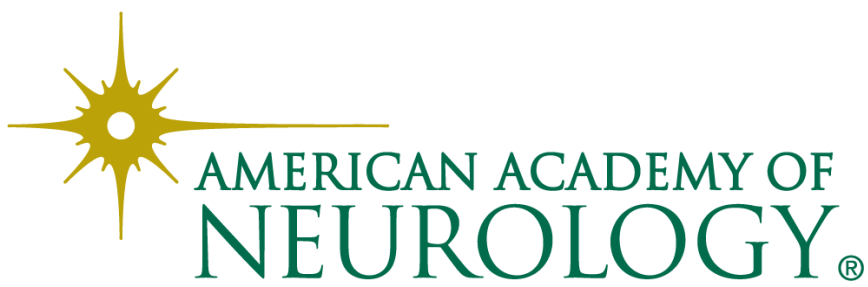

